\title{
Aortoiliac Artery Segment
}

National Cancer Institute

\section{Source}

National Cancer Institute. Aortoiliac Artery Segment. NCI Thesaurus. Code C116166.

The segment of the arterial system that includes the iliac artery and its orig in from the aorta. 